\title{
Does China's Outward Focused Journalism Engage a Constructive Approach? A Qualitative Content Analysis of Xinhua News Agency's English News
}

\author{
Xin Zhao ${ }^{a}$, Yu Xiang \\ a Division of Humanities and Social Sciences, Beijing Normal University-Hong Kong \\ Baptist University United International College, Zhuhai, China; ${ }^{b}$ School of Journalism \\ and Communication, Shanghai University, Shanghai, China \\ Corresponding author: Yu Xiang, yuxlovemayo@shu.edu.cn, School of Journalism and \\ Communication, Shanghai University, Shanghai, China, 200070.
}

Xin Zhao (Ph.D., Bangor University, ORCID ID: 0000-0001-6853-7224, xinzhao@uic.edu.hk) is an Assistant Professor of public relations and advertising at Beijing Normal University-Hong Kong Baptist University United International College. Yu Xiang (Ph.D., University of Westminster, yuxlovemayo@shu.edu.cn) is a Lecturer of international communication and China-Africa media studies at Shanghai University in Shanghai, China. 


\begin{abstract}
This study examines the rationalisation of the news frames of currencyrelated international economic interaction by analysing news articles from the "China Focus" column in China's state-run Xinhua News Agency. Thematic analysis of the main themes in the news articles shows dominant positive coverage of China's economic development. Using qualitative content analysis, it also investigates the breeding of the "emergence" of constructive journalism practices in China. It finds that Xinhua prioritises the frames of referring to solutions to the conflict and problem and mentioning the social and economic stability, sustainability, and prosperous development. The frames of moral judgement, conflict and its formation, and human interest are less applied in news articles. It bears elements of constructive journalism, but still needs efforts to make a clear division from positive journalism and Party journalism.
\end{abstract}

Keywords: China; currency; constructive journalism; framing; qualitative content analysis 


\section{Introduction}

The global expansion of China-based outward focused media institutions, which is known as the media "going-global" project (Hu \& Ji, 2012), has evoked the curiosity of international scholars about the journalistic approach deployed by Chinese outward focused state-run media organisations. Media platforms such as the Xinhua News Agency (XNA), China Daily, and China Central Television (CCTV) are usually acknowledged to be government sponsored - and monitored vehicles - whose role is largely to represent and disseminate the ideological agenda of Beijing. A few scholars have argued that the identifiable journalistic practices of these state media platforms can be regarded as providing an alternative journalistic approach to report international news (e.g. Zhang, 2014; Wekesa \& Zhang, 2014).

The official rhetoric of these state media organisations has shown a trend towards further localisation. The president of XNA, Cai Mingzhao, stated in 2018 'on reporting for an international audience': 'We uphold the journalistic principles of being true and comprehensive ... putting people first and cherishing a global vision' (Peng, 2018). As Zhang and Matingwina wrote in "Constructive Journalism: A New Journalistic Paradigm of Chinese Media in Africa": "rather than simply rebutting the Western media's overly critical and biased reporting ... China's state-led media are making efforts to produce their own content' (2016, p. 93). This paper, therefore, aims to contribute to the emerging discussions on the alternative approach of China's outward focused journalistic practices by concentrating on XNA and examining its English news articles on the currency-related international interaction from 2009 to 2016.

This article is composed of five main parts. First, it introduces the historic background of XNA as an outward looking state media organisation and the debates 
China's currency-related issues. Second, it contextualises the discussions on China's soft power initiatives through its outward focused state media and reviews the existing studies on constructive journalism with a focus on China. Then, it details the sampling procedures, the research method of qualitative content analysis, and the news framing typology, as well as thematic categorisation. Fourth, it unfolds the empirical findings of the journalistic practices featured by the constructive journalism of XNA's English news. Finally, it concludes that the constructive approach of XNA's English economic news on the topic of currency-related international relationships is applying a different reporting style than it employs in the more general news services, although such practices are, of course, relevant to the diplomatic and political agenda as designated by the government authorities in Beijing.

\section{XNA and currency-related international output}

\section{XNA and "China Focus"}

$\mathrm{XNA}$ is the official - and largest - state news agency in China and has long served as 'a government political and ideological apparatus for the ruling Chinese Communist Party (CCP)' (Hong, 2011, p. 377). The year 2009 witnessed the launch of the important and comprehensive "going-global" project of the Chinese media directed by the central government. Authoritative state-run media organisations such as XNA received a huge investment from the government for the global outreach (Hu \& Ji, 2012). According to an informant from XNA, the news agency has now covered over 180 nations worldwide (personal communication, 2019, March 11). China's outward focused news departments are also charged with the mission to "de-monopolise" the dominant discourse of Western media on global affairs, to promote the perspectives of China and strengthen its soft power (Hayden, 2012). 
In 2002, XNA launched the "China Focus" column, its first and most prominent service dedicated to introducing China's current affairs to overseas audiences and building a positive image of China in the global arena (China Press and Publishing Website, 2008).

To investigate the implementation of the agenda of promoting Chinese perspectives in the global sphere, it is important to examine the journalistic approach of China's state-run media in reporting controversial global issues. Therefore, this research chose to focus on the currency-related issues because of their significance to China as it undergoes a rapidly accelerating economy within the global system.

\section{China's currency-related economic interaction with others in the global sphere}

China's involvement in global currency-related issues (such as currency manipulation and devaluation, market-oriented exchange-rate reform, foreign currency reserves, currency law, and digital currency) arouses fierce discussions amongst global political, academic, and public circles, especially in the United States. In 2005, former US deputy secretary of state Robert Zoellick said: 'We need to urge China to become a responsible stakeholder in that system', and he specified that currency manipulation deterred the economic collaboration between China and the United States (2005, paragraph 9, emphasis in original). The American leadership also exhorted the Chinese government to implement a market-oriented exchange rate reform (e.g. Kerry et al., 2015; Kerry \& Lew, 2014).

The US foreign policy on China's currency was consistent for a decade until 2017 when Donald Trump said that he would not label China as a currency manipulator (Baker, Lee, \& Bender, 2017; Tang, 2018). This research focuses on the currencyrelated reports of "China Focus" between 2009 and 2016 to examine the journalistic approach of XNA in response to the relatively stable economic interaction between 
China and US, as well as other countries, during this period and whether such an approach can be identified with specific features. Therefore, the first research question this study aims to answer is:

RQ1: How did China's Xinhua News Agency rationalise the news frames of currency-related international economic interaction through its international English economic news?

\section{Soft power and constructive journalism}

"Soft Power", which is acknowledged as the ability of a nation 'to get what a country wants through attraction rather than coercion or payments', is regarded by the Chinese government as an important strategy to enhance its 'charm offensive' to either improve its continuing image as a somewhat isolated or detached communist country or challenge the dominant discourse of Western superpowers (Glaser \& Murphy, 2009, pp. 10-11; Nye, 1990). Accordingly, the outward focused communication of China's staterun media promoted by the "going-global" initiative has become a vital component of China's integral macro project for soft power augmentation (e.g. Hu \& Ji, 2012; Sun, 2010). The outward focused state-run media is entrusted with the mission of becoming 'genuine global players' and to compete 'for influence and credibility' in the field of international news reporting while establishing the national image that China aspires (Sun, 2015, pp. 400-406).

However, there appears to be a lack of consensus on the nature of the outward focused journalistic practices of China's state-run media. One group of scholars found that the reporting style aimed at enhancing the charm offensive of China (Grassi, 2014) is inheriting the domestic mainstream journalistic tradition of creating and presenting a harmonious picture of Chinese governance to its global readers and audiences (Zhang, 2013). For example, Sun (2010) found that China's media coverage on the natural 
disaster of the 2008 Sichuan earthquake forged a unified national image by using the tactics of media transparency, looking at the human-interest angles, and reporting on the organisation of the national mourning events. Similarly, Han, Sun, and Lu (2017) found that China's official newspapers constructed a collaborative image of China as an entity that proactively engaged in global efforts on climate change from 2005 to 2015 . This is congruent with Zhao's (2017) findings that XNA depicted China as being sincere and resolute in supporting global environmental protection, maintaining currency stability, and seeking more opportunities of international trade. Additionally, the news coverage of 25 domestic Chinese media websites about the "New Style of Great Power Relations" depicted a positive and cooperative U.S.-China relationship (Hinck, Manly, Kluver, \& Norris, 2016). This indicates that the media policy, which aims to generate a positive tone with reference to China's state-run media, is directly responding to the ideological agenda of the central government and has remained consistent with the Party line.

The 'highly positive, didactic, and openly value-oriented' news format and journalistic narrative observed in the news coverage of China's outward focused staterun media (Zhao, 1998, p. 27) is provoking more debates on the disputed propagandistic nature of China's global publicity policy. Chang and Ren (2018) argued that Party control of the innovative visual elements of photojournalism, TV news, animated cartoons, and online videos marks a new stage of the discursive legitimisation strategies deployed by the CCP. Others are concerned with the credibility and acceptance of China's media presence in the developing world (Xin, 2009) and suspicious about the objectivity of news reporting on the matters of human interests and social conflicts/crises because of the intervention of the government's ideological directives (Sun, 2010). Usually seen as propaganda (Edney, 2012) and the mouthpiece of CCP (Chang, 1989), the positive journalism displayed by the Chinese state-run media is 
questioned for being constrained by the central government whose aim is to indoctrinate and mobilise the public for power legitimisation. Instead of 'mak[ing] power accountable' (Entman, 2005, p. 48), the pro-China tone of its international news media is applied as a pivotal strategy to facilitate China's soft power projection (Edney, 2012).

It is especially evident in Africa where the news produced by Chinese state-run media such as CCTV-Africa is aimed at providing its readers and audiences a constructive narrative regarding the conflicts and crises in the local societies from a solution-oriented perspective (Greenslade, 2015). Local presenter of CCTV-Africa, Beatrice Marshall, said: "When you look at Western media, a lot of the time their strategy is to be combative. But what we want to do is say 'this is the issue, this is the challenge, and this is how it's being solved' rather than getting people to argue" (Greenslade, 2015, paragraph 15). Scholars such as Wekesa and Zhang (2014), therefore, argued that the journalism of China's outward focused state-run media is beyond just positive reporting but rather has drawn up an alternative journalistic framework that they called "constructive journalism". It hopes to construct China's own interpretations and narratives towards global issues (Boc, 2015; Zhang \& Mathingwina, 2016) and tries to win the hearts and minds of the audiences in the receiving countries, which is the very definition of soft power (Nye, 1990).

Discussions on the topic of constructive journalism are usually related to development journalism and peace journalism, which focus on the positive representation and the stimulation for solutions in the news content (Galtung, 2003; McIntyre, 2015; Wimmer \& Wolf, 2005; Zhang, 2014). Positive emotions in the news stories can develop readers' positive feelings, attitudes, and behavioural intentions, and effective solutions to a social problem in the news stories (McIntyre, 2015). Scholars interpret the "solutions" in the news articles differently. For McIntyre (2015), the 
solutions mentioned in the news articles are pre-existent and the news reporters serve as organisers and deliverymen of these solutions. Nevertheless, Zhang (2014) proposed a “solution-focused" perspective, which prefers to stimulate readers' reaction to the reported problems by providing informational news content instead of providing solutions, either pre-existing or potential, by journalists themselves. But Galtung argues that the academic focus on solutions in the news article should be expanded because the intention of the journalistic framework for peace (or development) subjects is to 'focus on conflict transformation' (2003, p. 177). Truthfulness is the baseline of honest journalism, but how to present the truth is the key to developing a peace approach for news reporting. As indicated in Table 1, Galtung suggested going deeper into the story not only by ferreting out the solutions but also the cause and development of the conflict.

[Table 1 near here]

The constructive or positive reporting style of China's outward focused media has been criticised for failing to 'deliver on one of the main mandates of journalism: acting as a watchdog and keeping those in power in check, rather than praising them for their success' (Verhoeven \& Gagliardone, 2012, paragraph 10). As Gagliardone and his colleagues (2010, p. 13) noted, although the media plays an indispensably crucial role in ensuring the successful involvement of China in foreign affairs, 'the idea of soft power initiative' does not easily translate into 'practical implementation'. But without doubt the diplomacy-oriented nature is blurring with the substance of the emerging “constructive journalism" elements observed in the practices of China's outward focused media. Based on the above review and discussion, this research attempts to examine the second research question:

RQ2: Is the journalistic practice of Xinhua News Agency on covering the currency-related international economic interaction pursuing an authentic 
constructive approach or following the agenda of the central government to enhance soft power?

\section{Research methods}

\section{Locating news articles}

News articles from XNA's “China Focus” from 2009 to 2016 are retrieved from Nexis UK (source: Xinhua General News Service ${ }^{1}$ ) based on the key words "HEADLINE(China Focus) and BODY(currency)". A total of 282 news articles are located. Excluding duplicates and non-relevant ones, a total of 274 news articles are selected. Table 2 shows the number of the selected news articles per year from 2009 to 2016.

[Table 2 near here]

\section{Qualitative content analysis}

A qualitative content analysis method is deployed by this research to find out how the journalistic practice of "China Focus" is responding to the "constructive journalism" discussion on China's outward focused media. The qualitative content analysis, rooted in 'literary theory, the social sciences and critical scholarship', refers to the 'rearticulation (interpretation) of given texts into new (analytical, deconstructive, emancipatory, or critical) narratives that are accepted within particularly scholarly communities' (Krippendorff, 2004, p. 17). Specifically, this research applies the approach of directed content analysis (Hsieh \& Shannon, 2005) by 1) referring to established generic news frames and being open to new frames and 2) defining the operational definition for each frame in the framing typology (see next section for a detailed explanation). To complement the descriptive interpretation of the news framing patterns in "China Focus", this study also illustrates the "rank order comparisons of 
frequency of codes' (Hsieh \& Shannon, 2005, p. 1, 283).

Although it counts the frequencies of the application of news frames in the articles, this study sticks to the qualitative research scholarship in the following ways. First, the generation of the frames considers the specific data (Morgan, 1993). The texts of the news are rearticulated into frames in a hermeneutic approach. The identification of the frames is based not only on the existing generic news frames but also generated from the selected data through careful and thorough readings. This procedure differentiates this study from the quantitative content analysis, which often neglects the speciality of datasets. Second, the numerical comparisons of the application frequencies of the news frames complements the interpretation of the patterns of news coverage in "China Focus" by relating the ranks to the Chinese socio-political background where China's journalism is grounded (Morgan, 1993). This is unlike the quantitative content analysis, which focuses on the data exclusively and thereby sets apart the data from the context. Previous studies have shown the feasibility of qualitative content analysis, especially the strategy of rank order comparisons, in answering questions such as the main attributes of innovations influencing educators' use of research (Neal, Neal, Lawlor, Mills, \& McAlindon, 2018) and the division of labour in wedding planning for remarrying individuals (Humble, 2009).

\section{News framing typology}

To reduce the subjective interference of the researchers, a framing typology is clearly defined before the analysis of the news texts (see Table 3). It is based on the definitions provided by Galtung for peace journalism as shown in Table 1 and Marsh's (2016, p. 180) framing categories used in her empirical study of China's constructive journalism (an extension and customisation of Semetko and Valkenburg's (2000, p. 100) 
framework). As indicated in Table 3, an additional frame looking at the "economic growth of China" is added to the frame typology to better rationalise the news discourse of "China Focus".

[Table 3 near here]

The frames of "conflict", "responsibility", and "solution" are intended to examine XNA's journalistic focus on solutions, a vital element of constructive journalism. As elaborated by Galtung (2003), McIntyre (2015), and Zhang (2014), the focus on solutions to the conflict, problem, and/or concern covered by the news stories is a key feature of the practice of constructive journalism. As stressed by Galtung (2003), being constructive in this strand of the journalistic profession also means that journalism should not give up its core functions of exposing the causes of the conflict and holding governments and officials accountable. This feature of constructive or peace journalism differentiates itself from positive journalism, which only covers happy and upbeat stories but lacks a commitment to journalism's core functions (McIntyre, 2015). For example, one news article from "China Focus" released on 23 November 2016 mentioned not only the 'depreciation pressure on yuan' because of 'a strong dollar backed by heightened expectations of an interest rate hike', but also the Chinese authorities' solutions for 'currency management' (“China Focus: Chinese yuan,” 2016). Therefore, the deployment of the frames of "conflict", "responsibility", and "solution" are of vital importance to this research to investigate the arguable constructive nature of XNA’s English economic news.

Additionally, the frames of "moral judgement", "stability", and "economic growth of China" are deployed to explore XNA's strategies to boost the positive emotions and reactions of readers. This is another important element for practicing constructive journalism. In McIntyre's (2015) study, the positive emotional conditions 
in news stories, expressed through discrete emotional words or described as an integral feeling of the message, are supposed to 'evoke elevation, hope, happiness, joy, pride, and excitement' in readers; negative emotional conditions are meant to 'evoke disgust, despair, sadness, guilt, worry, and anger'. The frame of "moral judgement" involves both agreement and disagreement with certain stances and/or activities, which may generate positive or negative emotions among the message receivers. For instance, the phrase 'The new U.S. monetary move has been widely criticised at home and abroad' (“China Focus: U.S. told,” 2010) contains negative judgement of U.S.'s policies on currency issues, which may negatively influence readers' emotions. Moreover, Marsh (2016) found that the frame of "stability" is among the top five frames used by CCTVAfrica in covering African issues, which is consistent with the priorities of the official Chinese domestic policy. The report by "China Focus" on, for example, enhancing liquidity risk management for 'the safety and stability of China's banking system' (“China Focus: Banking regulator," 2011) also reveals XNA's application of the "stability" frame. In addition to the element of "stability", the frame referring to the prosperous development of China's economy - "economic growth of China" is also included in the news framing typology as a unique component to investigate the Chinese state media. China's media discourse is found to be upbeat on representing U.S.China economic cooperation (Hinck et al., 2016) and on China's economic responsibilities in trade and currency (Zhao, 2017). We thus assume that XNA's English news articles tend to have a positive tone regarding China's overall economic situation when reporting the interrelated currency issues to alleviate the concerns and suspicions of readers and to generate positive emotions and reactions. News content introducing 'the Chinese economy firms with recent upbeat data' (“China Focus: 
China's reform," 2013) is regarded as positively applying the frame of "economic growth of China".

Finally, the "human interest" frame is also a significant element in the implementation of constructive and development journalism. As stated by McIntyre (2015, p. 78), the purpose of constructive journalism is to 'create more engaging and productive stories that improve individual and societal well-being'. Similarly, Zhang (2014) argued that constructive journalism should 'watch the society and government for the interest of the public' (p. 7) and 'empower the people' (p. 8). Their opinions are consistent with what Galtung (2003) explained as the people-oriented nature of this strand of journalism. Although the topic of currency-related international economic interaction seems to be globally oriented, it is closely related to the domestic economy of China because currency - both the value of the Chinese currency and its foreign reserves - influences many economic aspects such as consumption, inflation, international trade, and real estate prices (Zhao, 2017). Therefore, this study also investigates the application of the "human interest" frame in XNA's news stories to see if they linked the currency issues with the public's concerns and/or demands.

Based on the seven framing categories as shown in Table 3, the deductive approach of this research distils the interpretive schema or the narrative structure concerning the currency-related international economic interaction in the news articles issued by XNA's "China Focus". The unit of observation is the pertinent content of the news that complies with the definitions of the framing categories in Table 3. It is expected that through the qualitative content analysis of the news frames of "China Focus" represented in the 274 selected articles, the overall perspectives of XNA's journalistic approach on the topic of currency-related international interaction can be illustrated and studied. 


\section{Thematic categorisation}

To complement the qualitative content analysis, this study also deploys the thematic categorisation for 'identifying, organizing, and offering insights into patterns of meaning (themes)' across the news reports from “China Focus" in reporting China's currency-related international interaction (Braun \& Clarke, 2012, p. 57). As indicated in Table 5 in Appendix 2, four major types of themes were observed in the currencyrelated news of "China Focus": "positive reports on China's economy", "negative reports on China's economy", “China-U.S. economic interaction”, and "others”. Each type is composed of a few different themes.

\section{Findings and Discussion}

\section{Focusing more on "solution", less on "reason"}

The "solution" frame has been chosen as the principal approach used by "China Focus" in comparison with other frames such as "conflict", "responsibility", "moral judgement", and "human interest" especially from 2009 to 2014 (see Figure 1 which shows the trends of news framing in "China Focus" from 2009 to 2016).

[Figure 1 near here]

At $83.04 \%$, the "solution" frame towers above the others (see Figure 2 which shows the average percentage of the seven framing categories applied in the news in the eight years; more information is recorded in Table 4 in Appendix 1).

[Figure 2 near here]

The solutions provided in the news from "China Focus" are diverse, including:

- Applying a floating exchange rate mechanism ("China Focus: Chinese yuan," 2016); 
- Building China's cross-border yuan payment system and pushing yuan's internationalisation ("China Focus: CIPS seeks," 2016);

- Establishing credibility for consistent and transparent financial policymaking (“China Focus: China's forex," 2016);

- Supporting small and medium-sized companies (Lin \& Gao, 2009);

- Sustaining transformation of companies (Liu, 2009);

- Countries cooperating with each other in the global financial system reformation, regulation, and innovation (“China Focus: Boao annual,” 2009);

- Urging other countries to regulate their macroeconomic policies ("China Focus: Yuan's role," 2009).

Figure 1, however, shows that there was a drastic decline in the frequency of the "solution" frame to $55.56 \%$ in 2016 from the peak of $93.55 \%$ in 2009 . The fluctuation may have resulted from the shifts of China's macroeconomic policies or the changes in XNA's international communication strategies in response to Western political and media discourses. Nevertheless, even though the "solution" frame received less attention over the two years, it was still generally more prominent than the other frames.

Overall, the solution-oriented frame is an important characteristic of XNA's "China Focus". This finding is consistent with that of Marsh (2016) in that the "solution" frame is prioritised when reporting domestic issues in Africa. It also corresponds with Zhang's (2014) illustration on the deployment of constructive patterns of China's outward focused media activities. From the theoretical perspective, this finding resonates with the arguments of many scholars that the "solution approach" is necessary and key to the practice of constructive journalism (e.g. Galtung, 2003; McIntyre, 2015). However, such an emphasis by "China Focus" on providing solutions for the currencyrelated issues involving China is interpreted by others to be the result of XNA playing its role in China's state-run media as the government mouthpiece (Zhao, 2017). 
In contrast, the minimal percentage of the "responsibility" frame of "China Focus" shows that the solution-oriented approach of XNA is not as ideal as the theorists expect. The $36.37 \%$ of the "responsibility" frame as shown in Figure 2 is the lowest among all frames. The $52.27 \%$ of the "conflict" frame ranks fifth of the seven identified. Both figures indicate that compared with depicting a solvable situation for the readers, "China Focus" was reluctant to dig into the cause and development of the conflict. Figure 1 also shows that the two years of 2012 and 2013 witnessed a neglect of the "conflict" and "responsibility" frames in news stories. For example, in the 3 December 2013 news there was no explanation for the problems which motivated the government to introduce plans for the internationalisation of the Chinese yuan ("China Focus: Mightier yuan," 2013). Similarly, in the coverage of multi-lateral talks to establish a free trade agreement between China, Japan, and the Republic of Korea, the focus was exclusively on the movement of expanding trade settlements in local currencies without pointing out the conflict in currencies or the formation of the conflict ("China Focus: China, Japan,” 2012). This finding also echoes Marsh's (2016) observation that less concentration is put on the deeper reasons for conflicts. It would appear that the pursuit of Galtung for 'conflict transformation' (2003, p. 177) was not being thoroughly adopted in the news issued by "China Focus".

\section{Emphasising stability and China's economic growth}

In Figure 2, the average percentages of the frames of "stability and sustainability" and "economic growth of China" are $65.01 \%$ and $56.11 \%$ respectively, second and third amongst the seven frames. These two frames represent the journalistic elements that may provoke emotional responses amongst the readers.

More specifically, Figure 1 shows that the percentage of the "stability and sustainability" frame reached its peak in 2011 (81.25\%) while that of China's 
prosperous economic development was achieved in 2013 (70\%). Although both elements declined in 2014 to $44.12 \%$ and $35.29 \%$ respectively, the consistency in delivering positive and promising messages mostly about the development in China, as well as the world, was not interrupted.

Consistently, China's economic development received a commandingly positive coverage in "China Focus" as shown in the thematic analysis (see Figure 3 which shows the application frequencies of the news themes referring to China's currency-related international interaction from 2009 to 2016; more information is recorded in Table 5 in Appendix 2). The themes ranged from the domestic development of the Chinese markets to the increasingly important role of China in the global sphere.

[Figure 3 near here]

To convey the messages of stability and sustainability, "China Focus" reported:

- Detailed macroeconomic policies, such as China's prudent monetary policies (“China Focus: China to,” 2011), the stability of China's banking system ("China Focus: Banking regulator," 2011), and the stable exchange rate ("China Focus: Shanghai-HK stock," 2014);

- China's overall economic stability ("China Focus: China confident," 2014; “China Focus: China's yuan,” 2011);

- The urges for collaboration in maintaining the stability of the global monetary environment (“China Focus: BRICS nations,” 2011).

The prosperous and hopeful development of China's economy in an overall sense was depicted when covering:

- The trade and economic exchanges among countries along the Silk Road economic belt ("China Focus: Cities ink," 2013) and between China and Africa (“China Focus: China-Africa," 2014);

- The outstanding performance and reform in the Shanghai free trade area ("China Focus: Shanghai FTZ,” 2014); 
- The upbeat trend of the economic growth (“China Focus: China's reform," 2013).

Moreover, this study found that the negative evaluations of the U.S.'s quantitative easing policy and the positive evaluations of China's market-oriented exchange reform were frequently deployed to highlight a principled and upstanding image of China to the international readers. The percentage of the "moral judgement" frame at $55.49 \%$ ranks fourth among the seven frames (see Figure 2). It was most frequently applied in $2010(81.40 \%)$ (see Figure 1). The thematic analysis shows a consistency that the year 2010 witnessed the most journalistic attention on the negative influence of American economic policies on China and the contradictory interests between the two biggest economies in the world (see Figure 3; refer to Table 5 for more information). In that year, “China Focus” openly criticised the U.S.'s quantitative easing monetary policy through a series of news articles. They attributed the trade imbalance to the 'excessive consumption' in the U.S. (“China Focus: Economists say,” 2010), blamed the 'rising U.S. trade protectionism' and described the 'inappropriate and untenable' currency policies (“China Focus: China says,” 2010) as a 'dangerous gamble' (“China Focus: U.S. told,” 2010), and urged it to "take a responsible attitude as a major reserve currency issuing country' (“China Focus: U.S. told,” 2010) (see also Jiang \& Guo, 2010; Liu, 2010; Liu, Ma, \& Jiang, 2010).

These messages depicted a stable and promising status quo and future for China that is proactive in implementing suitably designed policies and cooperating with other countries and regions. These elements, however, blur the nature of XNA's journalistic practice as it is difficult to define it as constructive journalism or positive journalism. 


\section{A lack of focus on human interest}

Figure 2 shows that the average percentage of the "human interest" frame (41.13\%) ranks sixth among the seven categories, indicating the lack of attention on the humanistic perspective in framing the currency-related international interaction by "China Focus". The "human interest" frame was mostly applied in 2010 with $72.09 \%$ of news articles being identified with this frame (see Figure 1). This news frame was applied to represent the mutual impact between the currency-related international economic interaction and the ordinary public: for example, China's medium-sized companies (“China Focus: China's largest," 2010) and employment and consumption in a general sense (“China Focus: China's central,” 2010). Nevertheless, no journalistic focus was placed on the individual opinions as that there was a lack of interviews with or quotations from consumers or job applicants. Relevant content was only represented as, for example, by observations that the Chinese authorities should 'better reflect the market's opinion on the currency' (“China Focus: China seeks,” 2015) and a firm yuan 'will further hamper employment' (“China Focus: Yuan sees,” 2015). It indicates that the issues of the currency-related international economic interaction were politicised by XNA in a rather abstract way instead of relating it closely with people's daily lives through a humanistic angle. Therefore, it may not effectively 'capture and retain audience interest' (Semetko \& Valkenburg, p. 96) as popular journalism is supposed to do.

\section{Conclusion}

In summary, based on the customised news framing categories, this research finds that XNA's "China Focus" column prioritises the "solution" frame, among all the seven frames, when reporting the subject of currency-related international economic 
interaction. In contrast, it pays much less attention to the frames of "conflict" and "responsibility". The frames of "stability and sustainability" and "economic growth of China" rank second and third, slightly outnumbering the frame of "moral judgement". XNA seldom used the "human interest" frame in its news output and tended to only focus on the general groups if it was applied. The thematic categorisation also finds the coverage of China's economy to be predominantly positive.

This study finds that XNA's journalistic practice does include some elements of constructive journalism, but it does not distinguish itself entirely and clearly from positive journalism (McIntyre, 2015) or Party journalism (Chang, 1989). It emphasises the "solution" frame, which is constructive in nature but does not sufficiently explain the cause and development of conflict and problem. It jumps to conclusions about what is legitimate and what is irresponsible without adequately illustrating the substance of legitimacy and responsibility. Such a reporting style can indeed provoke emotional reactions amongst readers but not necessarily provide constructive access for them to rationally understand the truthfulness of news. The lack of human interest in XNA's news agenda once again points back to the inherent logic of XNA as a government directed institution that is structurally instructed to promote the ideology of the government instead of the ordinary public, which is contradictory to the pursuit of constructive journalism as a means of empowering ordinary people.

Therefore, this study suggests that China's state-run outward focused media, as shown in the case of XNA, is following a different journalistic practice, which distinguishes itself from the mainstream journalistic practices of Western international media. It features a mixed result promoted by outward focused publicity and the politiceconomic agenda of the Chinese government. As indicated in the news agenda of "China Focus", the diplomatic/political emphasis is constraining the development of 'a 
consistent strategy or a fully distinctive way of reporting the news' (Marsh, 2016, p. 12). Currency-related topics regarding "who should shoulder the responsibilities", "what is just and legitimate" and so on were represented by "China Focus" in a solution-oriented and positive way which is, to some extent, still following the basic logic of a realistic international relationship.

The epistemological divergence between the theoretical paradigms of soft power and constructive journalism is perceived in the case study of XNA in this research. State media such as XNA inevitably acts as the 'agent' of the Chinese government in the construction and dissemination of official interpretations of major global affairs, which rather collides with the goal of constructive journalism in terms of being independent and objective. Nevertheless, as that media industry has never existed in isolation from human society but is rather an extension of it, the journalistic professionalism should not be merely about the media industry but the grander background arena that encompasses societies and nations.

On the one hand, the salient preference of XNA for depicting China as a growing, and invincible, economic power is due to the political and economic agenda of China to promote its own discourse in the world. On the other hand, such an agenda to some extent also implies a potential alternative for developing countries to participate politically and economically in creating a de-westernised global order. Therefore, more studies are welcome to contribute to this subject by bringing in inter-disciplinary knowledge and analysis to further explore the establishment of Chinese outward focused media and constructive journalistic practices. An analysis of China's journalistic practices in international communication during the current, and escalating, trade war, particularly with the U.S., and especially after 2018, could be a good start. 


\section{Notes}

1. Xinhua General News Service is an authoritative English-language source for information on Chinese government affairs, economic performance, and Chinese views on world affairs (LexisNexis, 2018). 


\section{References}

Baker, G., Lee, C. E., \& Bender, M. C. (2017, April 12). Trump says dollar 'getting too strong,' won't label China a currency manipulator. Wsj.com. Retrieved from https://www.wsj.com/articles/trump-says-dollar-getting-too-strong-wont-label-chinacurrency-manipulator-1492024312

Boc, A. (2015). The power of language: Globalizing “The Chinese Dream”. Fudan Journal of the Humanities and Social Sciences, 8(4), 533-551.

Braun, V., \& Clarke, V. (2012). Thematic analysis. In H. Cooper, P. M. Camic, D. L. Long, A. T. Panter, D. Rindskopf, \& K. J. Sher (Eds.), APA handbook of research methods in psychology, Vol. 2: Research designs: Quantitative, qualitative, neuropsychological, and biological (pp. 57-71). Washington, DC: American Psychological Association.

Chang, J., \& Ren, H. (2018). The powerful image and the imagination of power: The 'new visual turn' of the CPC's propaganda strategy since its 18th National Congress in 2012. Asian Journal of Communication, 28(1), 1-19.

Chang, W. H. (1989). Mass media in China: The history and the future. Ames, IA: Iowa State University Press.

China Press and Publishing Website. (2008). Xinhuashe "zhongguo jujiao" jujiao waimei shixian [Xinhua News Agency "China Focus” Column Attracts Foreign Media's Attention]. Chinaxwcb.com. Retrieved from http://www.chinaxwcb.com/index/200810/08/content_152383.htm

Edney, K. (2012). Soft power and the Chinese propaganda system. Journal of Contemporary China, 21(78), 899-914.

Entman, R. M. (2005). The nature and sources of news. In G. Overholster, \& K. H. Jamieson (Eds.), Institutions of American democracy: The press (pp. 48-65). New York, NY: Oxford University Press.

Gagliardone, I., Repnikova, M., \& Stremlau, N. (2010). China in Africa: A new approach to media development? Report for the Programme in Comparative Media Law and Policy (PCMLP). Oxford: University of Oxford.

Galtung, J. (2003). Peace journalism. Media Asia, 30(3), 177-180.

Glaser, B. S., \& Murphy, M. E. (2009). Soft power with Chinese characteristics: The ongoing debate. In C. McGiffert (Ed.), Chinese soft power and its implications for the United States: Competition and co-operation in the developing world (a report of the CSIS Smart Power Initiative) (pp. 10-26). Washington, DC: Centre for Strategic \& International Studies. 
Grassi, S. (2014). Changing the narrative: China's media offensive in Africa. Friedrich-EbertStiftung. Retrieved from http://library.fes.de/pdf-files/iez/10700.pdf

Greenslade, R. (2015, August 20). Chinese media in Africa illustarte difference from western media. Theguardian.com. Retrieved from https://www.theguardian.com/media/greenslade/2015/aug/20/chinese-media-in-africaillustrate-difference-from-western-media

Han, J., Sun, S., \& Lu, Y. (2017). Framing climate change: A content analysis of Chinese mainstream newspapers from 2005 to 2015. International Journal of Communication, 11, 23.

Hayden, C. (2012). The rhetoric of soft power: Public diplomacy in global contexts. Lanham, MD: Lexington Books.

Hinck, R. S., Manly, J. N., Kluver, R. A., \& Norris, W. J. (2016). Interpreting and shaping geopolitics in Chinese media: The discourse of the 'New style of great power relations'. Asian Journal of Communication, 26(5), 427-445.

Hong, J. (2011). From the world's largest propaganda machine to a multipurposed global news agency: Factors in and implications of Xinhua's transformation since 1978. Political Communication, 28(3), 377-393.

Hsieh, H. F., \& Shannon, S. E. (2005). Three approaches to qualitative content analysis. Qualitative Health Research, 15(9), 1,277-1,288.

Hu, Z., \& Ji, D. (2012). Ambiguities in communicating with the world: The "Going-out" policy of China's media and its multilayered contexts. Chinese journal of communication, 5(1), 32-37.

Humble, Á. M. (2009). Technique triangulation for validation in directed content analysis. International Journal of Qualitative Methods, 8(3), 34-51.

Kerry, J., Biden, J., Liu Y., Wang Y., Lew, J., \& Yang, J. (2015, June 23). The U.S.-China Strategic \& Economic Dialogue/Consultation on People-to-People Exchange. State.gov. Retrieved from http://www.state.gov/secretary/remarks/2015/06/244120.htm

Kerry, J., \& Lew, J. (2014, June 30). Interview With Wang Guan of CCTV. State.gov. Retrieved from http://www.state.gov/secretary/remarks/2014/06/228904.htm Krippendorff, K. (2004). Content analysis: An introduction to its methodology (2nd ed.). Thousand Oaks, CA: Sage.

LexisNexis. (2018). Source information: Xinhua General News Service. Nexis.com. Retrieved from https://www.nexis.com/results/shared/sourceInfo.do?csi=8078 
Marsh, V. (2016). Africa through Chinese eyes: New frames or the same old lens? African news in English from China Central Television, compared with the BBC. In M. Bunce, S. Franks, \& C. Paterson (Eds.), Africa's media image in the 21st Century: From the 'heart of darkness' to 'Africa rising' (pp. 177-189). London: Routledge.

McIntyre, K. E. (2015). Constructive journalism: The effects of positive emotions and solution information in news stories (Doctoral dissertation). Retrieved from https://cdr.lib.unc.edu/indexablecontent/uuid:83b99a42-951c-4205-a129-44c9bf7ad8f3

Morgan, D. L. (1993). Qualitative content analysis: A guide to paths not taken. Qualitative Health Research, 3(1), 112-121.

Neal, J. W., Neal, Z. P., Lawlor, J. A., Mills, K. J., \& McAlindon, K. (2018). What makes research useful for public school educators? Administration and Policy in Mental Health, 45(3), 432-446.

Nye, J. S. Jr. (1990). Bound to lead: The changing nature of American power. New York, NY: Basic Books.

Peng, Y. (2018). Xinhua president spells out reporting principles. Xinhuanet.com. Retrieved from http://www.xinhuanet.com/english/2018-01/23/c_136917873.htm

Semetko, H. A., \& Valkenbug, P. M. (2000). Framing European politics: A content analysis of press and television news. Journal of Communication, 50(2), 93-109.

Sun, W. (2010). Mission impossible? Soft power, communication capacity, and the globalization of Chinese media. International Journal of Communication, 4, 54-72.

Sun, W. (2015). Slow boat from China: Public discourses behind the 'going global' media policy. International Journal of Cultural Policy, 21(4), 400-418.

Tang, F. (2018, July 20). How the US stopped complaining about China's exchange rate policy. South China Mornig Post. Restrived from https://www.scmp.com/news/china/economy/article/2120681/how-us-stoppedcomplaining-about-chinas-exchange-rate-policy

Verhoeven, H., \& Gagliardone, I. (2012, December 19). Opinion: China's positive spin on Africa. $C N N$. Retrieved from https://edition.cnn.com/2012/12/18/opinion/china-mediaafrica-verhoeven-gagliardone/index.html

Wekesa, B., \& Zhang, Y. (2014, May). Live, talk, faces: An analysis of CCTV's adaption to the African media market (CCS discussion paper). Stellenbosch: Stellenbosch University Centre.

Wimmer, J., \& Wolf, S. (2005). Development journalism out of date? Retrieved from https://core.ac.uk/download/pdf/12161927.pdf 
Xin, X. (2009). Xinhua news agency in Africa. Journal of African Media Studies, 1(3), 363-377.

Zhang, X. (2013). How ready is China for a China-style world order? China's state media discourse under construction. Ecquid Novi: African Journalism Studies, 34(3), 79-101.

Zhang, Y. (2014, September 10-11). Understand China's media in Africa from the perspective of constructive journalism. Paper presented at the International Conference on China and Africa Media, Communications and Public Diplomacy, Beijing, China.

Zhang, Y., \& Matingwina, S. (2016). Constructive journalism: A new journalistic paradigm of Chinese media in Africa. In X. Zhang, H. Wasserman, \& W. Mano (Eds.), China's media and soft power in Africa: Promotion and perceptions (pp. 93-105). New York, NY: Palgrave Macmillan.

Zhao, X. (2017). Responsible China: A critical discourse analysis of soft power projection through transnational media (Doctoral dissertation). Retrieved from http://e.bangor.ac.uk/10270/2/Zhao\%20PhD\%202017.pdf

Zhao, Y. (1998). Media, market, and democracy in China: Between the Party line and the bottom line. Urbana, IL: University of Illinois Press.

Zoellick, R. B. (2005, September 21). Whither China: From membership to responsibility? State.gov. Retrieved from http://2001-2009.state.gov/s/d/former/zoellick/rem/53682.htm 
Table 1. Peace/Conflict journalism by Johan Galtung (2003, p. 178).

\begin{tabular}{|c|c|}
\hline $\begin{array}{l}\text { Peace/ } \\
\text { Conflict- } \\
\text { oriented }\end{array}$ & $\begin{array}{l}\text { - Explore conflict formation; x parties, y goals, z issues; general } \\
\text { "win-win" orientation; } \\
\text { - Open space, open time; causes and outcomes anywhere, also in } \\
\text { history/culture } \\
\text { - Making conflicts transparent; } \\
\text { - Giving voice to all parties; empathy, understanding; } \\
\text { - See conflict/war as problem, focus on conflict creativity; } \\
\text { - Humanization of all sides; more so the worse the weapons; } \\
\text { - Proactive: prevention before any violence/war occurs; } \\
\text { - Focus on invisible effects of violence (trauma and glory, damage } \\
\text { to structure/culture). }\end{array}$ \\
\hline $\begin{array}{l}\text { Truth- } \\
\text { Oriented }\end{array}$ & $\begin{array}{l}\text { - Expose untruths on all sides; } \\
\text { - Uncover all cover-ups. }\end{array}$ \\
\hline $\begin{array}{l}\text { People- } \\
\text { Oriented }\end{array}$ & $\begin{array}{l}\text { Focus on suffering all over; on women, aged, children, giving } \\
\text { voice to the voiceless; } \\
\text { - Give name to all evil-doers; } \\
\text { - Focus on people peacemakers. }\end{array}$ \\
\hline $\begin{array}{l}\text { Solution- } \\
\text { Oriented }\end{array}$ & $\begin{array}{l}\text { - } \text { Peace }=\text { non-violence }+ \text { creativity; } \\
\text { - Highlight peace initiatives, also to prevent more war; } \\
\text { - Focus on structure, culture, the peaceful society; } \\
\text { - Aftermath: resolution, re-construction, reconciliation. }\end{array}$ \\
\hline
\end{tabular}


Table 2. Coverage of the currency-related international economic interaction in "China Focus", 2009-2016.

\begin{tabular}{lcccccccc}
\hline $\begin{array}{l}\text { Year } \\
\text { Number } \\
\text { of }\end{array}$ & 2009 & 2010 & 2011 & 2012 & 2013 & 2014 & 2015 & 2016 \\
articles & 31 & 43 & 48 & 34 & 30 & 34 & 36 & 18 \\
\hline
\end{tabular}


Table 3. News framing typology.

\begin{tabular}{l|l}
\hline Conflict & The news story mentions disagreement, problem, and/or concern. \\
\hline Responsibility & $\begin{array}{l}\text { The news story mentions the party who is the cause of the } \\
\text { conflict. }\end{array}$ \\
\hline Solution & $\begin{array}{l}\text { The news story mentions action and/or stance to solve and/or } \\
\text { ease the conflict. }\end{array}$ \\
\hline Morality & $\begin{array}{l}\text { The news story bears moral judgement which indicates just and } \\
\text { legitimate stance and/or behaviour. }\end{array}$ \\
\hline Human Interest & $\begin{array}{l}\text { The news story applies a human angle by showing how } \\
\text { individuals and/or common groups are affected. }\end{array}$ \\
\hline $\begin{array}{l}\text { Stability and } \\
\text { Sustainability }\end{array}$ & $\begin{array}{l}\text { The news story mentions the maintenance and/or establishment } \\
\text { of stability and sustainability of the parties related. }\end{array}$ \\
\hline $\begin{array}{l}\text { Economic Growth } \\
\text { of China }\end{array}$ & $\begin{array}{l}\text { The news story mentions the prosperous past, present, and/or the } \\
\text { promising future of China's economic development. }\end{array}$ \\
\hline
\end{tabular}




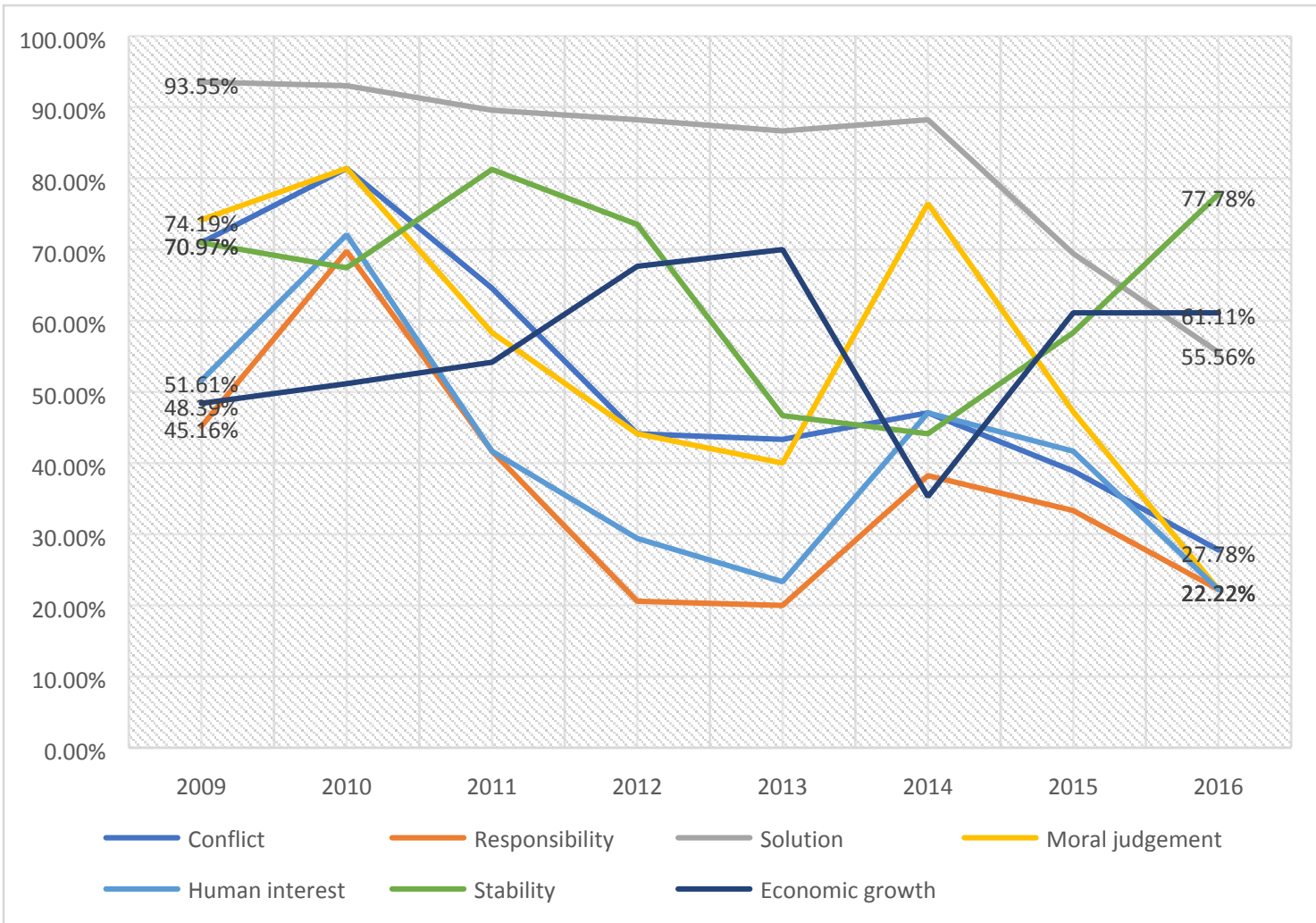

Figure 1. Trends of news framing from 2009 to 2016. 


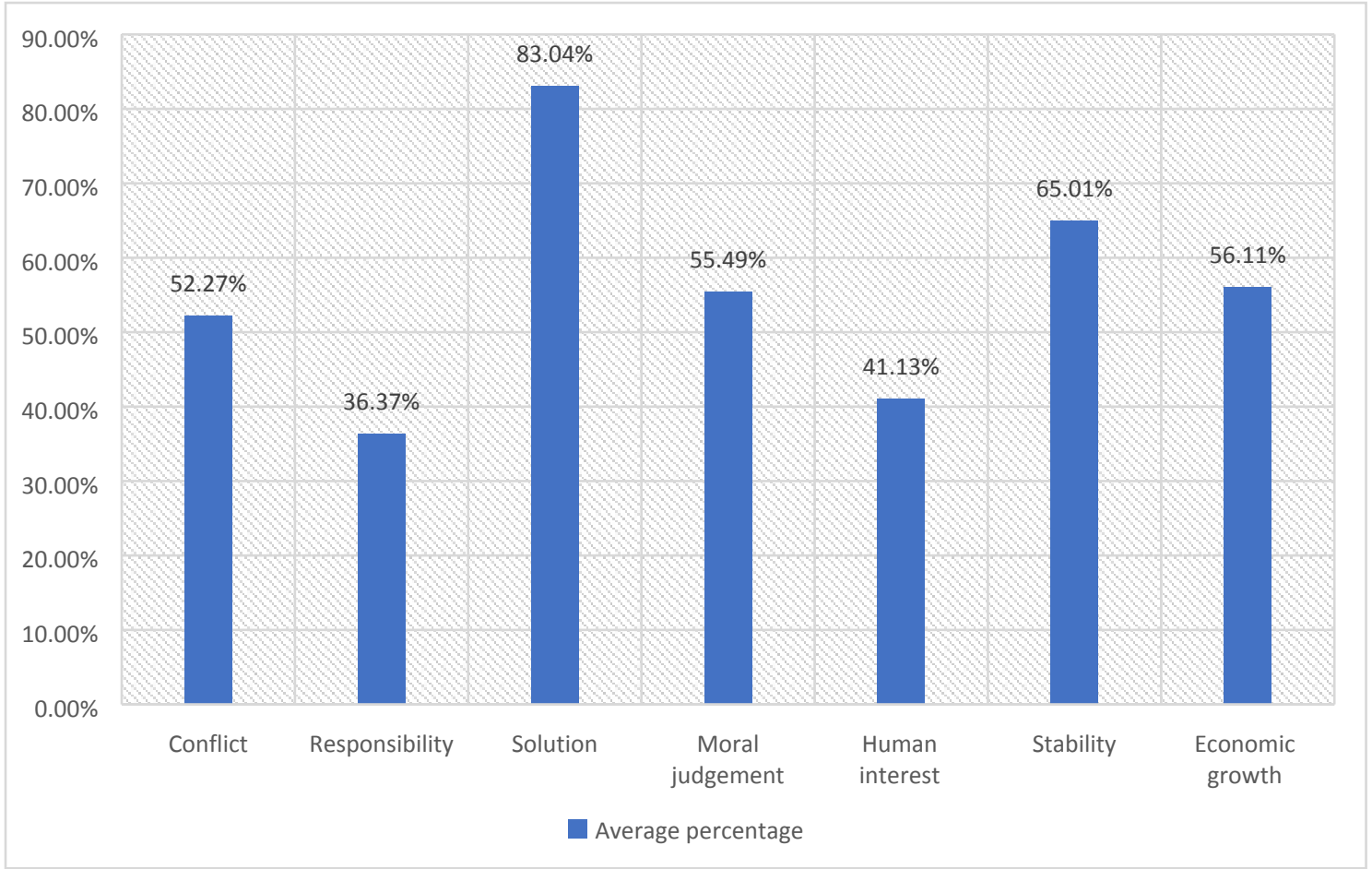

Figure 2. Average percentage of framing categories from 2009 to 2016. 


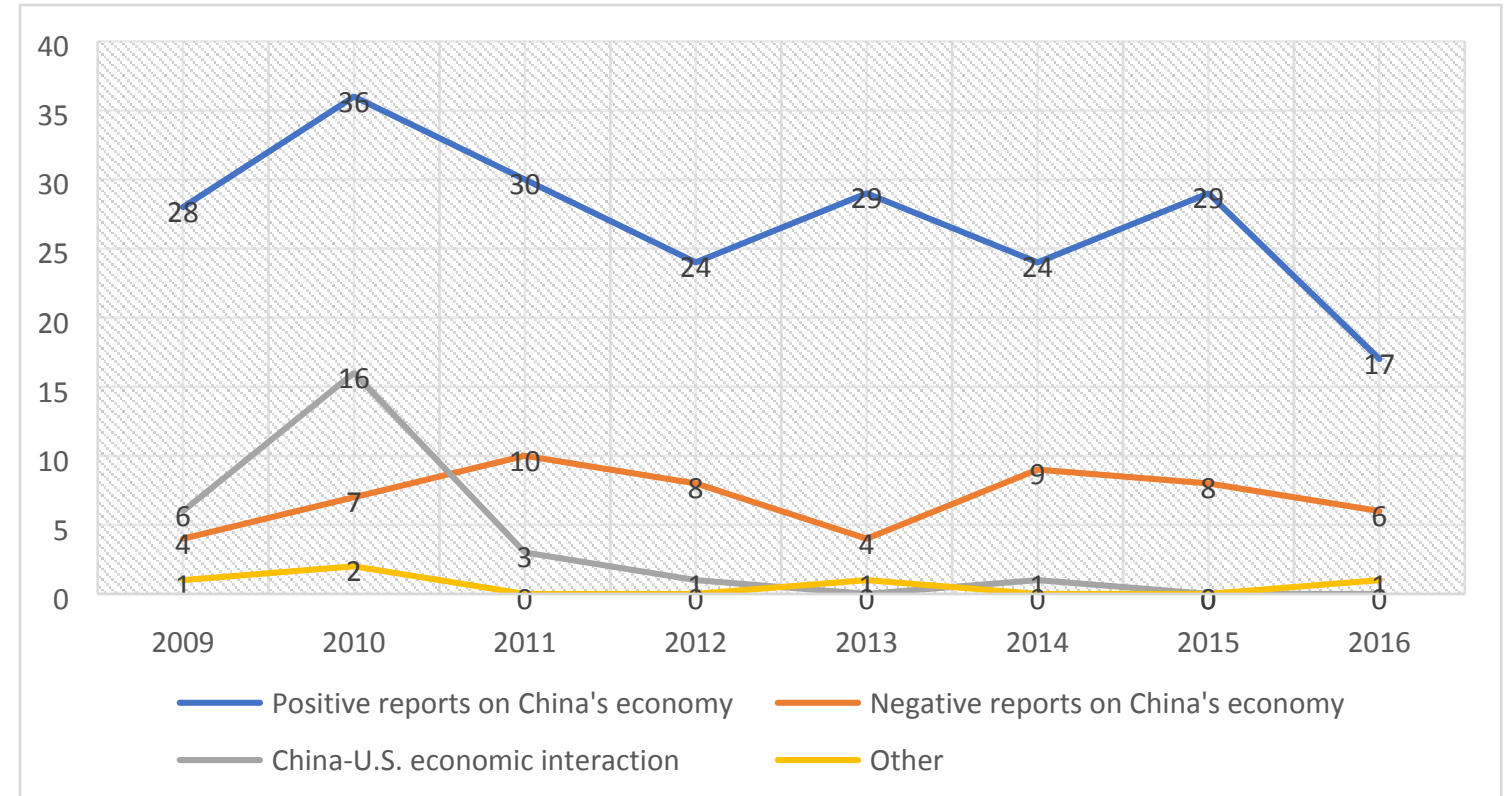

Figure 3. Frequencies of application of thematic categories from 2009 to 2016. 


\section{Appendix 1}

Table 4. Distribution of news framing categories.

\begin{tabular}{cccccccc} 
Category & Conflict (\%) & Responsibility (\%) & Solution (\%) & Morality (\%) & Human (\%) & Stability (\%) & Economy (\%) \\
\hline 2009 & $22(70.97)$ & $14(45.16)$ & $29(93.55)$ & $23(74.19)$ & $16(51.61)$ & $22(70.97)$ & $15(48.39)$ \\
2010 & $35(81.40)$ & $30(69.77)$ & $40(93.02)$ & $35(81.40)$ & $31(72.09)$ & $29(67.44)$ & $22(51.16)$ \\
2011 & $31(64.58)$ & $20(41.67)$ & $43(89.58)$ & $28(58.33)$ & $20(41.67)$ & $39(81.25)$ & $26(54.17)$ \\
2012 & $15(44.12)$ & $7(20.59)$ & $30(88.24)$ & $15(44.12)$ & $10(29.41)$ & $25(73.53)$ & $23(67.65)$ \\
2013 & $13(43.33)$ & $6(20.00)$ & $26(86.67)$ & $12(40.00)$ & $7(23.33)$ & $14(46.67)$ & $21(70.00)$ \\
2014 & $16(47.06)$ & $13(38.24)$ & $30(88.24)$ & $26(76.47)$ & $16(47.06)$ & $15(44.12)$ & $12(35.29)$ \\
2015 & $14(38.89)$ & $12(33.33)$ & $25(69.44)$ & $17(47.22)$ & $15(41.67)$ & $21(58.33)$ & $22(61.11)$ \\
2016 & $5(27.78)$ & $4(22.22)$ & $10(55.56)$ & $4(22.22)$ & $4(22.22)$ & $14(77.78)$ & $11(61.11)$ \\
\hline
\end{tabular}




\section{Appendix 2}

Table 5. Thematic categorisation and frequencies of application.

\begin{tabular}{|c|c|c|c|c|c|c|c|c|c|}
\hline Types & Themes & 2009 & 2010 & 2011 & 2012 & 2013 & 2014 & 2015 & 2016 \\
\hline Positive reports on & Ascent of China-related economic index & 2 & 6 & 12 & 6 & 4 & 3 & 1 & 1 \\
\hline \multirow[t]{5}{*}{ China’s economy } & Correction of inaccurate report on China's economy & 3 & 3 & 0 & 0 & 3 & 1 & 3 & 1 \\
\hline & Growth of China's economic markets & 5 & 6 & 4 & 7 & 8 & 7 & 7 & 7 \\
\hline & $\begin{array}{l}\text { China's growing multi-lateral economic relation with } \\
\text { foreign countries (U.S. excluded) }\end{array}$ & 7 & 4 & 6 & 5 & 7 & 6 & 6 & 5 \\
\hline & $\begin{array}{l}\text { Growing importance of China's economy in the global } \\
\text { sphere }\end{array}$ & 2 & 2 & 2 & 1 & 1 & 1 & 1 & 1 \\
\hline & $\begin{array}{l}\text { China's strategies to cope with financial dilemmas and } \\
\text { to boost the economic development }\end{array}$ & 9 & 15 & 6 & 5 & 6 & 6 & 11 & 2 \\
\hline Negative reports on & Downturn of China-related economic index & 3 & 2 & 5 & 4 & 3 & 2 & 6 & 3 \\
\hline \multirow{2}{*}{ China’s economy } & Economic disputes related to China & 0 & 1 & 0 & 2 & 1 & 3 & 0 & 1 \\
\hline & Difficulties faced by China's economy & 1 & 4 & 5 & 2 & 1 & 4 & 2 & 2 \\
\hline \multirow[t]{3}{*}{$\begin{array}{l}\text { China-U.S. economic } \\
\text { interaction }\end{array}$} & $\begin{array}{l}\text { Bilateral economic interaction between China and the } \\
\text { United States }\end{array}$ & 0 & 5 & 0 & 1 & 0 & 0 & 0 & 0 \\
\hline & $\begin{array}{l}\text { Negative influence of the economic policies of the } \\
\text { United States }\end{array}$ & 2 & 4 & 0 & 0 & 0 & 0 & 0 & 0 \\
\hline & $\begin{array}{l}\text { Contradicted interest between the economies of China } \\
\text { and the United States }\end{array}$ & 4 & 7 & 3 & 0 & 0 & 1 & 0 & 0 \\
\hline Others & International economic events & 1 & 2 & 0 & 0 & 1 & 0 & 0 & 1 \\
\hline
\end{tabular}




\section{Appendix 3}

A list of cited news articles:

China Focus: Banking regulator to enhance liquidity risk management for Chinese banks. (2011, October 12).

China Focus: Boao annual conference opens, urging Asian countries to cooperate in financial crisis. (2009, April 18).

China Focus: BRICS nations seek common stance, shared prosperity. (2011, April 14).

China Focus: China confident of weathering QE exit shocks. (2014, January 24).

China Focus: China, Japan, ROK announce plan for FTA talks, give "great" attention to NE Asia stability. (2012, May 13).

China Focus: China says U.S. currency act violates WTO rules. (2010, September 30).

China Focus: China seeks to stabilize yuan amid depreciation. (2015, February 4).

China Focus: China to continue prudent monetary policy, inflation control. (2011, November 16).

China Focus: China-A frica cooperation to boost mutual development. (2014, May 7).

China Focus: China's central bank reaffirms moderately loose monetary policy, moderate credit growth in 2010. (2010, January 6).

China Focus: China's forex reserves data may improve due to a stable yuan. (2016, August 7).

China Focus: China's largest trade fair opens amid yuan appreciation worries. (2010, October 15).

China Focus: China's reform energizes the world. (2013, November 6).

China Focus: China's yuan exceeds symbolic 6.50 ratio against USD for first time. (2011, April 29).

China Focus: Chinese yuan breaks 12-day losing streak. (2016, November 22).

China Focus: CIPS seeks greater share of cross-border yuan payments. (2016, March 26).

China Focus: Cities ink Silk Road economic belt agreement. (2013, November 29).

China Focus: Economists say U.S. currency bill little help to its economy. (2010, September 26).

China Focus: Mightier yuan brightens prospects of bank's business. (2013, December 3).

China Focus: Shanghai FTZ boosts China's economic reforms. (2014, September 29).

China Focus: Shanghai-HK stock link to bolster yuan's internationalization. (2014, November 17).

China Focus: U.S. told to "explain" new monetary policy. (2010, November 5).

China Focus: Yuan's role presents dilemma for Chinese policymakers. (2009, April 8).

China Focus: Yuan sees increased volatility as depreciation pressure mounts. (2015, January 29).

Jiang, T., \& Guo, X. (2010, November 10). China Focus: Experts call for G20 transformation, criticize U.S. quantitative easing. Liu, J. (2009, May 12). China Focus: China says external demand key to growth as exports sink for sixth month.

Liu, J. (2010, March 12). China Focus: China tells Obama stronger yuan no help to fill trade gap. 
Lin, J. \& Gao, T. (2009, December 20). China Focus: China wins applause as economic recovery accelerates.

Liu J., Ma, S., \& Jiang, T. (2010, February 8). China Focus: Analysts say China should not yield to Obama's hard-line on yuan. 